\title{
Spatiotemporal analysis of fusariosis in black pepper crops
}

\author{
Ana Carolina Lyra Brumat '; Marcelo Barreto da Silva "; Edney Leandro da Vitória II' \\ Ivoney Gontijo IV; Antônio Fernandes Souza v; Ismael Lourenço de Jesus Freitas VI
}

\begin{abstract}
The objective of this work was to study the temporal and spatial dynamics of Fusarium wilt in black pepper plants. Plants were evaluated each two month during a year in nine areas planted with black pepper located in the Northern region of the Espiritu Santo state, Brazil. In each area with 500 plants in a black pepper field, we take the location of each plant and evaluated the incidence of the fusariosis. From these evaluations, a cumulative map of diseased plants within the selected area was obtained. Temporal progress of fusariosis was studied by means of the cumulative counting of the diseased plants incidence as a function of time and adjustment of these data to biological growth models. The spatial progress of the disease was analyzed by the Dispersion Index and the adjustment of the Law of Taylor. Analyzing the spatial distribution pattern of the disease in the field a predominantly aggregated pattern was verified. The highest disease progress period for all planted areas was observed starting in November, coinciding with the harvesting season, a time of high anthropic influence.
\end{abstract}

Keywords: Diesease; Spatial Analysis; Incidence

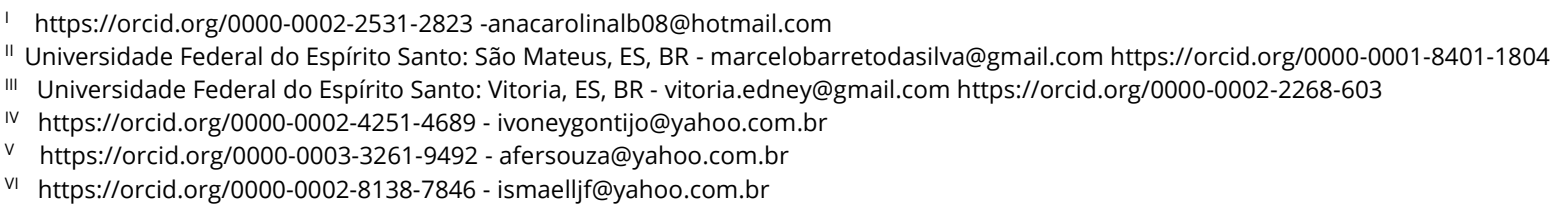




\section{INTRODUCTION}

Black pepper (Piper nigrum L.), is one of the most popular spices in the world, widely used as a condiment in food processing and preparation (NAIR, 2011).

Brazil is one of the main countries producing and exporting black pepper, with the state of Para being responsible for $79 \%$ of the production, the Espírito Santo state for $13 \%$ and the states of Bahia, Maranhao, Ceara, Paraiba and Amapa producing together $8 \%$ of the national production (Instituto Brasileiro de Geografia e Estatística [IBGE], 2016).

Black pepper has the third place in the ranking of exportations from the Espírito Santo state. During the first semester of 2013, 3.6 thousand tons of black pepper were exported to the U.S.A. and different countries from the E.U. and Asia (Companhia Nacional de Abastecimento [CONAB], 2016).

The black pepper plantations fields evaluated, are concentrated in the Northern region of the Espírito Santo, where this crop found favorable climatic conditions and flat areas which facilitate management practices.

Many factors limit the expansion of black pepper plantation, among them plant diseases of difficult management (Dias, 2006). Fusariosis, caused by the fungus Fusarium solani f.sp. piperis (FSP) (SHAHNAZI, et al., 2012), outstands due to its capability to reduce the lifespan of black pepper plants, thus resulting in pronounced productivity losses (ZACCARDELLI; et al., 2008).

This disease generally starts in some randomize plants, evolving to bigger areas and making productivity economically impracticable (VENTURA; COSTA, 2004). During the stages of establishment of the pathogen plant growth is normal. However, symptoms rapidly occur, starting in the lowest part of the plant and gradually expanding to the plant apex, causing drop of internodes and leaves thus, resulting in plants totally deprived of leaves. Examining the radicular system it is possible to observe the absence of small roots and root hairs as well as the occurrence of root rot, thus limiting water and nutrient absorption and leading to plant death (KUEH; GUMBEK; WONG, 1993; SITEPU; MUSTIKA, 2000). 
In commercial plantations of black pepper fusariosis causes significant productivity losses. FSP has a restrict occurrence in Brazil (CARNAÚBA, et al., 2007) and few information are available in the literature associating the dissemination and etiology of the fungus in plants of black pepper.

The main hypothesis is that dissemination of black pepper's fusariosis is facilitated by anthropic interference like weed control and harvest.

The study of the spatiotemporal progress and dissemination of plant diseases is essential for the correct characterization of a pathosystem. It gives support to understand the epidemiology, the efficiency of dispersion of the pathogen and delivers information about the influence of cultural, biological and environmental factors on the population dynamics of pathogens (VIDAL, et al., 2004). This set of information is useful for the decision-making regarding the management of any pathosystem (BERGAMIN FILHO, et al., 2004).

In this respect, the objective of this work was to study the spatial and temporal dynamics of fusiarosis in black pepper plants, in order to understand the variables that contribute the infection of healthy plants.

\section{MATERIAL AND METHODS}

\subsection{Study area}

Localization and incidence of diseased black pepper plants were evaluated each 60 days from July 2010 to September 2011 in the county of São Mateus, North of Espírito Santo state.

Nine fields of black pepper were selected (Table 1) for this study. Within each field an area containing 500 plants was delimited. 
Table 1 - Characterization of planting areas monitored to study the spatiotemporal progress of Fusariosis in black pepper in the county of São Mateus - ES.

\begin{tabular}{l|c|c|c|c|c}
\hline Area & $\begin{array}{c}\text { Age } \\
\text { (months) }\end{array}$ & Variety & Tutoring & $\begin{array}{c}\text { Spacing } \\
\mathbf{( m )}\end{array}$ & Previous Cultures \\
\hline A & 14 & Bargantina & Eucalyptus & $2,5 \times 2,0$ & $\begin{array}{c}\text { Coffee, callien-pepper, okra, } \\
\text { coconut, black pepper }\end{array}$ \\
\hline B & 22 & Bargantina & Eucalyptus & $2,5 \times 2,0$ & $\begin{array}{c}\text { Coffee, callien-pepper, okra, } \\
\text { cassava, black pepper }\end{array}$ \\
\hline C & 12 & Bargantina & $\begin{array}{c}\text { Re-used } \\
\text { Wood }\end{array}$ & $2,0 \times 2,0$ & Coffee, black pepper, grass \\
\hline D & 36 & Bargantina & $\begin{array}{c}\text { Re-used } \\
\text { Wood }\end{array}$ & $3,0 \times 2,0$ & Coffee, grass, lemon, black \\
pepper
\end{tabular}

Disease incidence was evaluated searching for characteristic symptoms through the visual inspection of plants. A diseased plant was considered one showing symptoms of leaf dropping, branch and internodes dropping within the upper third portion of the plant, death of upper branches and/or dead plants. The presence (grade 1) or absence of symptoms (grade 0) and the relative position of each plant were recorded in an Excel® worksheet, obtaining a map of all plants within the plantation areas for each evaluation date. During the evaluation data of rain precipitation and mean temperature were recorder daily at the Meteorological Station of São Mateus-A616 from the National Institute of Meteorology (Instituto Nacional de Meteorologia [INMET], 2016), and from these data mean values for monthly variables were obtained (Figure 1). 
Figure 1 - Monthly mean values for mean temperature and rain precipitation during 2010 and 2011 in the county of São Mateus - ES

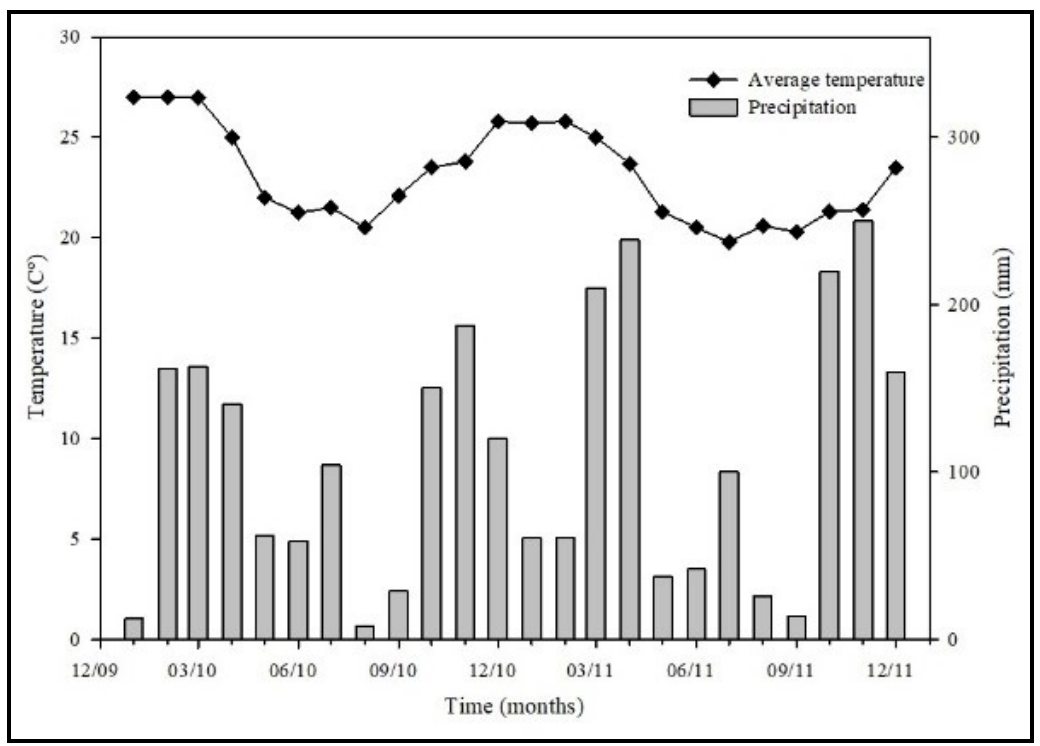

Source: INMET

\subsection{Analysis of temporal disease progress}

The temporal analysis consisted in the cumulative plotting of plant disease incidence as a function of time for each planted area evaluated, which originated a disease progress curve. Disease progress curves were adjusted to epidemiological models by means of linear regression, using the software Statistica 9.0 (Tulusa, Statsoft). The models testes were:

Monomolecular - y=1-(1-y0)e-rt

Logístic $-\mathrm{y}=1 /(1+[(1-\mathrm{y} 0) / \mathrm{y} 0] \mathrm{e}(-\mathrm{rt})$

Gompertz - y = e(-In(y0)exp (-rt))

Where $\mathrm{y}=$ disease quantity, $\mathrm{y} 0$ = initial quantity of disease, $r=$ rate of disease progress and $t=$ time. The adjustment degree of data for each model was evaluated by the higher values of the determination coefficient of the regression analysis $\left(\mathrm{R}^{2}\right)$ 
and the lower values of the mean square error (QMR) (Jesus Junior, Pozza, Vale, MoraAguilera, 2004).

\subsection{Analysis of spatial disease progress}

To study the spatial dynamics of the disease, three areas with different developmental stages were chosen. Each map obtained from evaluations was subdivided in smaller sub-areas (quadrats), with the aid of the software Microsoft Office Excel ${ }^{\circledR}$. Quadrats of 2x2 meters were used, forming two lines and two columns. The disease incidence $(p)$ was determined for each quadrat. This variable was defined as the estimative of the probability of a plant being infected in a determined area and was calculated by the equation:

$$
p=\sum X i / n N
$$

Where $\sum X i=$ sum of the number of plants with symptoms within each quadrat i, $\mathrm{n}=$ number of plants within each quadrat and $\mathrm{N}=$ total number of quadrat in each area.

Then, the observed variance (Vobs) and the estimated binomial variance (Vbin) were calculated,

$$
\text { Vbin }=p(1-p) / n
$$

Being $p=$ disease incidence within the parcel and $n=$ number of plants in the quadrat;

$$
\text { Vobs }=\sum(x i-n p)^{2} / n^{2}(N-1)
$$

Being $\mathrm{Xi}=$ number of diseased plants in the quadrat, $\mathrm{N}=$ total number of quadrats. 
From the Vbin and Vobs data, the dispersion index (ID) was, which generated information regarding to the tendency of diseased plants to be next to another diseased plant in sub-areas of the exanimated plot, in each evaluation; and the adjustment to the Law of Taylor, which indicated the tendency of aggregation along the whole epidemic.

The ID was estimated for each area and each evaluation through the equation:

$\mathrm{ID}=$ Vobs/Vbin

The $X^{2}$ (qui-square) test was applied for ID values obtained in each quadrat in order to verify of the calculated value was higher or equal to 1 at $5 \%$ significance level. ID values significantly equal to 1 denote that fusiarosis is randomly distributed in the field. ID values significantly higher than 1 represents aggregated diseased plants.

To determine the adjustment to the Law of Taylor of each studied area, the algorithm of Vbin and Vobs from each evaluation was estimated, before performing a linear regression. The $\mathrm{F}$ test was applied to verify significance between log (Vbin) and $\log$ (Vobs). The suitability of the adjustment of the linear model to the data was evaluated by observing the values of the determination coefficients (R2) and patterns of the residues' distributions. If values $A=0$ and $b=1$ it means the disease occurs randomly. If the value of $A$ is higher than zero and $b=1$ the spatial distribution of Fusariosis occurs in an aggregate manner. If the value of $A$ is higher than zero and $b$ is higher than 1 the aggregation level increases with the increment of disease incidence. The regression equation was evaluated for area, through the test at 5\% probability.

\section{RESULTS AND DISCUSSION}

\subsection{Analysis of temporal disease progress}

Studying the temporal progress of fusariosis in black pepper we verified that disease incidence increased in all monitored areas, as showed in Figure 2. All areas 
showed disease increase during November with areas D, E, F, G and I showing constant increment of fusariosis incidence in black pepper plants until the last evaluation.

The highest growth period of fusariosis incidence coincided with the harvest period and with the increment of the mean temperature and rain precipitation in the region (Figura 1).

Figure 2 - Temporal progress of Fusariosis in black-pepper areas in the county of São Mateus - ES between July 2010 and September 2011. Arrows show the harvest period of black pepper.
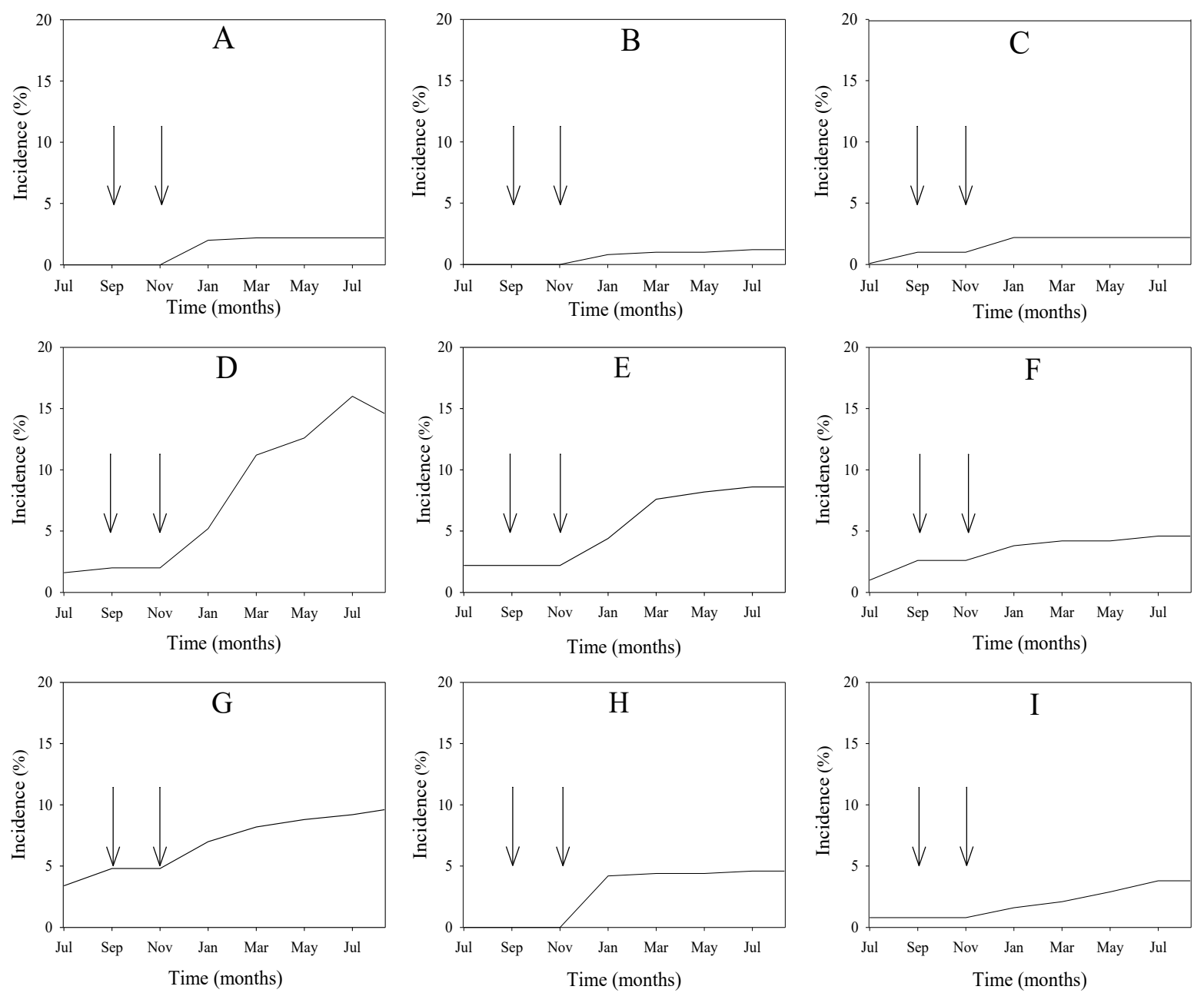

According with Bergamim Filho et al. (2000) environmental conditions are directly related with the performance of soil pathogens as in the case of FSP, primarily, temperature and humidity. In the case of F. solani, temperatures between 
25 - $35{ }^{\circ} \mathrm{C}$ promoted the evolution and development of the disease in the field (Bedendo, 2005), contributing for a faster reproduction, infection and dissemination.

The period of harvest is the period with the highest anthropic influence in balck pepper, evidenced by the alternated manipulation of infected and healthy plants, use of ladders and movement of soils by dragging bags containing harvested fruits. Ladders are fixed directly in the soil and used to harvest bunches in the higher parts of the plants, which may contribute to disseminate the pathogen in the field, once FSP has reproductive and resistance structures produced in the soil, which may be disseminated along with soil particles, even in the absence of host plants (ZACCARDELLI, et al., 2008).

During the harvest period, plants loss some leaves, branches and fruits, resulting in plant stress and mechanical damages that facilitate entry of pathogens.

All disease incidence curves fitted better to the Monomolecular mathematical model (Table 2), where the R2 varied from 0.68 to 0.95 and the lowest values of the QMR were observed, when compared to other models.

Table 2 - Summary of the linear regression analysis used to evaluate the adjustment of the progression curve of fusariosis in pepper plantations of different ages

\begin{tabular}{l|c|c|c|c|c|c}
\hline \multirow{2}{*}{ Area } & \multicolumn{2}{|c|}{ Gompertz } & \multicolumn{2}{c}{ Logistic } & \multicolumn{2}{c}{ Monomolecular* } \\
\cline { 2 - 7 } & $\mathbf{R}^{\mathbf{2}}$ (\%) & QMR & $\mathbf{R}^{\mathbf{2}(\%)}$ & QMR & $\mathbf{R}^{\mathbf{2}(\%)}$ & QMR \\
\hline A & 0.730 & 0.062837 & 0.731 & 0.435080 & 0.786 & 0.000864 \\
\hline B & 0.728 & 0.218253 & 0.715 & 2.074547 & 0.811 & $7.35 \mathrm{E}-06$ \\
\hline C & 0.625 & 0.003778 & 0.625 & 0.068683 & 0.625 & $1.59 \mathrm{E}-05$ \\
\hline D & 0.889 & 0.013622 & 0.867 & 0.147814 & 0.921 & 0.000362 \\
\hline E & 0.818 & 0.008265 & 0.809 & 0.092532 & 0.833 & 0.000170 \\
\hline F & 0.865 & 0.005232 & 0.853 & 0.126110 & 0.899 & $8.87 \mathrm{E}-06$ \\
\hline G & 0.850 & 0.002113 & 0.837 & 0.019408 & 0.881 & $6.42 \mathrm{E}-05$ \\
\hline $\mathrm{H}$ & 0.609 & 0.144286 & 0.606 & 1.062388 & 0.681 & 0.000189 \\
\hline I & 0.940 & 0.001681 & 0.927 & 0.035438 & 0.959 & $6.41 \mathrm{E}-06$ \\
\hline
\end{tabular}

$\mathrm{R}^{2}=$ Determination coefficient of the disease incidence. QMR= Mean square error.

(*) Shows the mathematical model which best fitted to the disease progress curve. 
According Vale et al. (2004), monocyclic diseases adjust better to the monomolecular model while polycyclic diseases are better represented by the logistic model, supporting the results obtained in the present work with fusariosis, a plant disease caused by a soil pathogen, which is characteristically monocyclic.

Variation coefficients with values under 0.65 in their respective areas are evidencing young plantations, which have not reach yet the production stage, limiting the occurrence and dissemination of the disease.

\subsection{Analysis of spatial disease progress}

The spatial distribution of fusiarosis on black pepper was studied in three of the nine monitored areas monitored bimonthly (Figure 3). Three plantations with different ages were selected the area $\mathrm{C}$ with one year old, area $\mathrm{D}$ with three years old and area I with aproximatelly one and a half years old. Different areas were selected to verify which were the main factors related to the disease dissemination implicated in the epidemic progress, once it was hypothesized that harvest in contaminated areas was a prominent factor.

According to the ID values, area C showed random spatial distribution of symptomatic plants in all evaluations; area I, initially showed random distribution, but aggregated spatial distribution from the fourth evaluation until the last; area D, showed aggregated spatial distribution of symptomatic plants from the second evaluation until the last (Table 3).

The ID calculated for all three areas was associated with the plantation's age, where older areas showed higher ID values. Therefore, area D, with three years old, showed ID values higher that 2 starting during the fifth evaluation, which is considered indicative for high aggregation according Maffia et al. (1993). 
Figure 3 - Spatial distributions maps of black pepper plants with symptoms of Fusariosis in areas C, D, I in São Mateus, ES. Filled squares represent symptomatic plants and empty squares represent healthy plants.

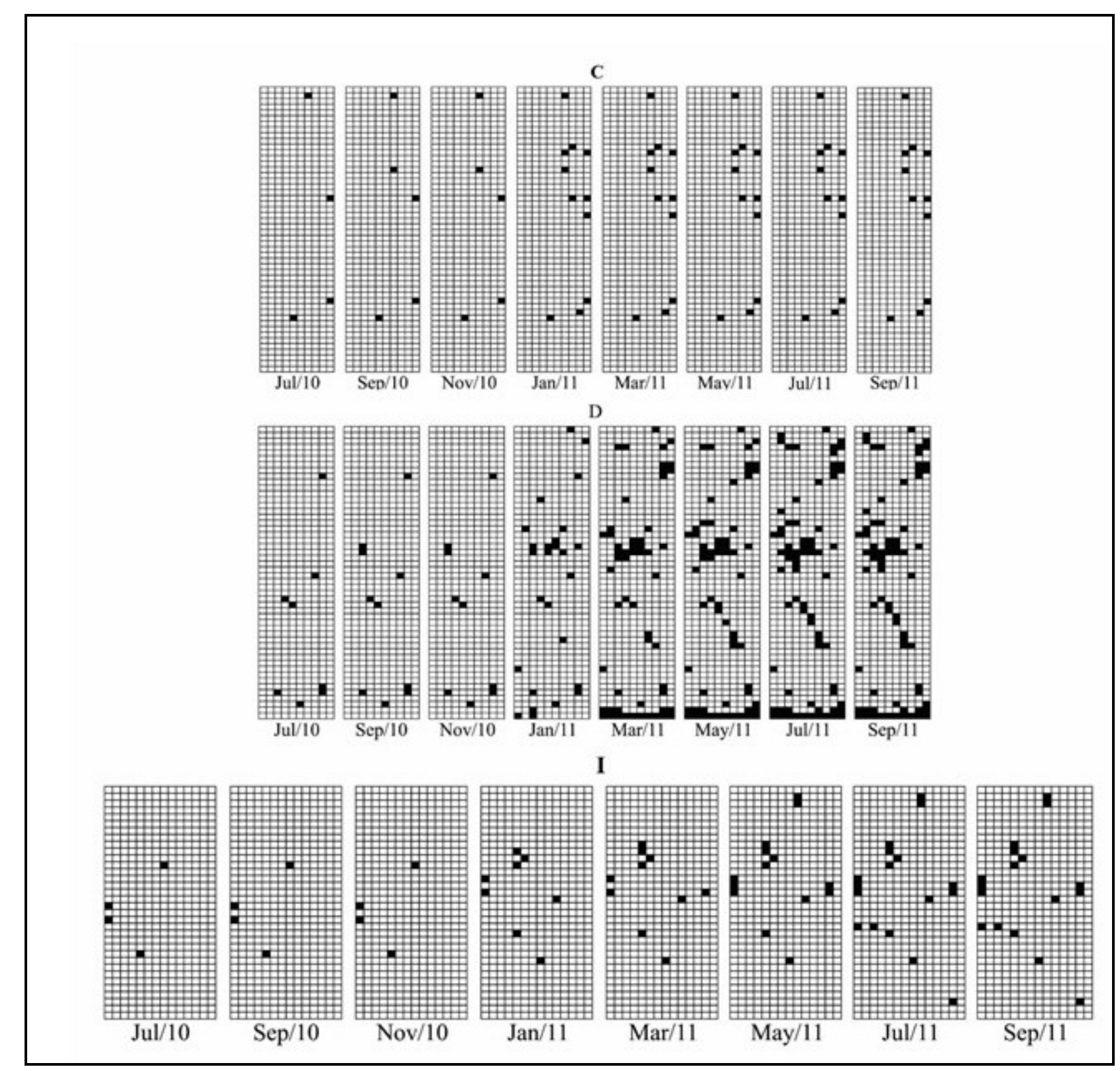

According to the Taylor's Law adjustment, all three areas under study showed an aggregated distribution of fusariosis, which may vary according to the incidence (Figure 4). Dissemination of the disease among adjacent plants increased with the incidence of fusariosis, especially in older plantations.

The spatial distribution of the disease started in a random fashion, suggesting the pathogen was randomly distributed in the field. Latter, this pattern changed to aggregate, showing a slow dissemination process of the disease from plant-to-plant. 
Table 3 - Dispertion indexes (Vobs/Vbin) of Fusariosis in black pepper in areas C, D and I

\begin{tabular}{c|c|c|c}
\hline \multirow{2}{*}{ Evaluations (days) } & \multicolumn{3}{|c}{ Areas } \\
\cline { 2 - 4 } & C & D & I \\
\hline 0 & 0.976 & 1.095 & 0.975 \\
\hline 60 & 0.970 & $1.261^{*}$ & 0.975 \\
\hline 120 & 0.970 & $1.261^{*}$ & 0.975 \\
\hline 180 & 1.118 & $1.298^{*}$ & 1.203 \\
\hline 240 & 1.118 & $2.188^{*}$ & $1.344^{*}$ \\
\hline 300 & 1.118 & $2.129^{*}$ & $1.554^{*}$ \\
\hline 360 & 1.118 & $2.545^{*}$ & $1.344^{*}$ \\
\hline 400 & 1.118 & $2.09^{*}$ & $1.344^{*}$
\end{tabular}

(*) Shows values statistically superior to 1 . Being ID=1: random distribution of symptomatic plants in the area, and $\mathrm{ID} \neq 1$ : aggregated distribution of symptomatic plants in teh area.

Figure 4 - Implementation of the Law of Taylor. Correlation of the observed variance logarithm (log Vobs) and the logarithm of the binomial variance (log Vbin) for the accumulated data of Fusariosis incidence in black pepper plants in the areas C, D and I. Each point represents a variation of the disease, the line represents the binomial line $($ Vobs $=$ Vbin)

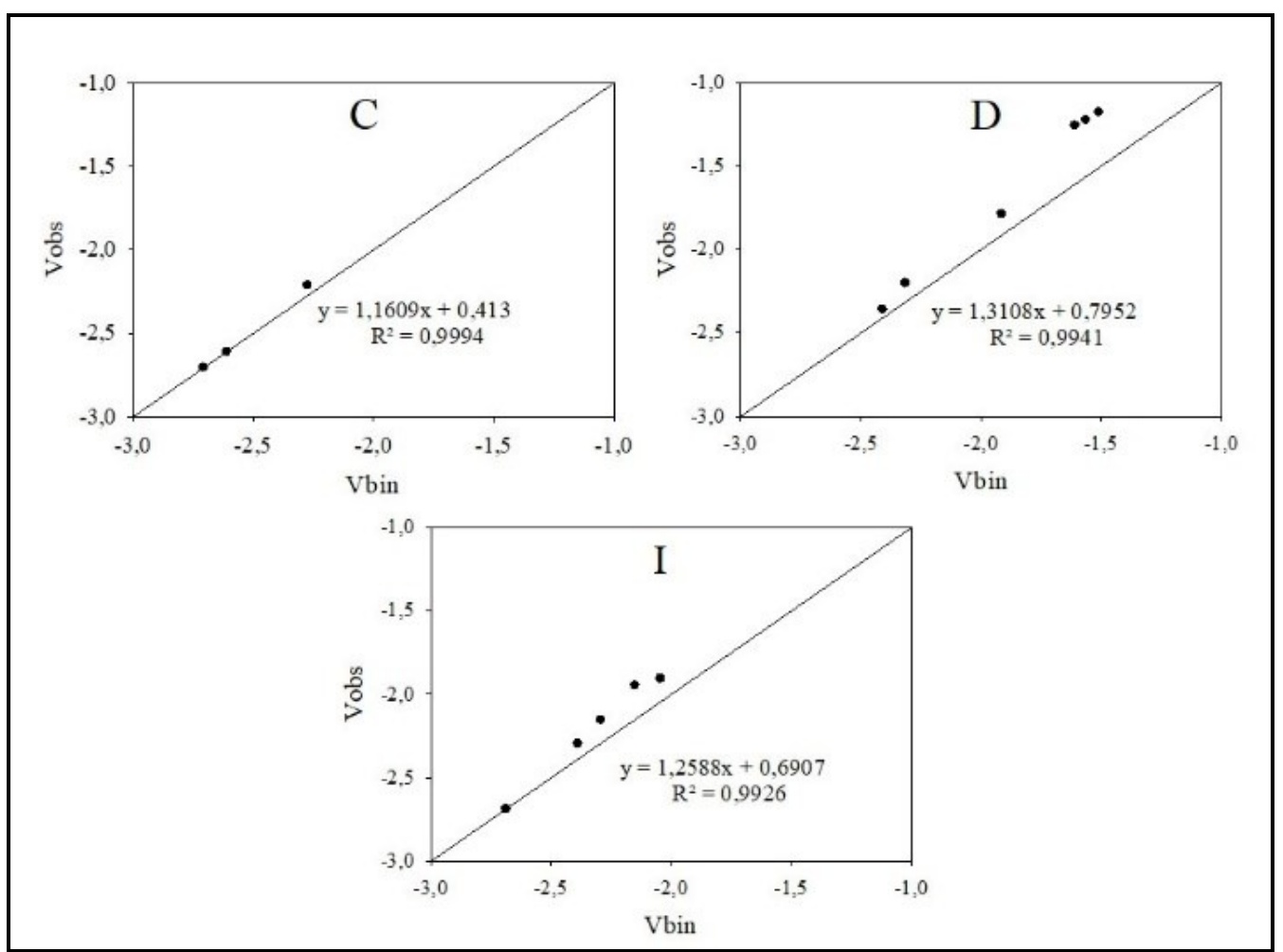


The fact of the disease having a random distribution at the beginning of the evaluations suggests the disease is disseminated by long distance factors, such as contaminated seedlings and cuttings. In Table 1 it is possible to distinguish that all three evaluated areas, C, D and I, reutilized cuttings from previous plantation. However according to the farmers, there was no disease observed in the previous plantation. This fact evidences the disease was disseminated through infected seedlings during the establishment of the plantation. Amorim e Pascholati (2011) stated that seedlings are the main mode for long distance dissemination of diseases.

The aggregate distribution of the disease occurring in older plantations first, as in plantation $D$, suggests that older plots are subject to management practices as soil plowing, manual weeding, transit of machines and specially a higher number of harvests. Practices, which become the main dissemination factor of Fusiarosis in black pepper after the disease is present in the area.

Understanding the epidemiology of the pathogen by means of its spatial and temporal distribution may be useful to guide the implementation of control measurements that will minimize the dissemination of the disease in the field, aiming the reduction of dead plants. During harvest, a potential management procedure would be the creation of management zones, consisting in the differentiation of areas with and without fusariosis, associated to the eradication of plants in an advanced stage of the disease, once activities related to harvest are shown as the main factor for dissemination of the pathogen.

Cultural control measures such as elimination of weeds that may serve as host plants for plant pathogens, use of uncontaminated agricultural tools and minimum soil plowing, may be applied during the whole plant cycle in order to reduce the dissemination of FSP.

As the disease evolved towards an aggregated distribution and showed a higher growth rate during the harvest period, it is possible to determine that the main disease dissemination factor among contiguous plants, within the same plantation line, consists in the anthropic action and plant stress during the harvest period. 


\section{CONCLUSIONS}

The fusariosis in black pepper fields presented typical behavior of monocyclic disease, with higher growth rate during harvest.

Disease distribution begins randomly, evolving into aggregate behavior characteristic of soil pathogens spread by seedlings.

\section{REFERENCES}

AMORIM L., PASCHOLATI SF. Ciclos das relações patógeno-hospedeiro. In: Amorim, L, Rezende, J.A.M., \& Bergamin Filho, A. Manual de Fitopatologia: Princípios e conceitos. São Paulo: Agronômica Ceres. 2011;1,59-100.

BEDENDO, I.P. Ambiente e doença (2005). In: Bergamin Filho, A., Kimati, H. \& Amorim, L. Manual de fitopatologia: Princípios e conceitos. São Paulo: Agronômica Ceres. $1,331-342$.

BERGAMIN FILHO A, HAU B, AMORIM L, JESUS JUNIOR WC. Análise espacial de epidemias. In: Vale, F.X.R., Jesus Junior, W.C. \& Zambolim, L. Epidemiologia aplicada ao manejo de doenças de plantas. 2001;1,195-240.

BERGAMIN FILHO A, HAU B, AMORIM L.,LARANJEIRA FF. Análise espacial de epidemias. Revisão Anual de Patologia de Plantas, Passo Fundo: Gráfica e Editora Padre Berthier dos Missionários da Sagrada família. 2000;17,155-218.

CARNAÚBA JP, SOBRAL MF, AMORIM EPR, SILVA IO. Ocorrência de Fusarium solani f. sp. piperis em Pipper nigrum no estado de Alagoas. Summa Phytopathologica. 2007; 33(1),96-97.

CONAB - Companhia Nacional de Abastecimento. Conjuntura pimenta-do-reino no Espírito Santo (2016). Retrieved http://www.conab.gov.br

DIAS AG. O cultivo da pimenteira-do-reino: Produção de especiarias de qualidade. Vitória ES: Sementes Vitória. 2000;1(1), 300.

GERAUD G, SPIERINGS EL, KEYWOOD C. Tolerability and safety of frovatriptan with short- and long-term use for treatment of migraine and in comparison with sumatriptan. Headache. 2002;42 Suppl 2:S93-9.

IBGE - Instituto Brasileiro de Geografia e Estatística. Banco de dados (2016). Retrieved http://www.ibge.gov.br.

INMET - Instituto Nacional de Meteorologia (2016). Retrieved http://www.inmet.gov.br.

JESUS JUNIOR WC, POZZA EA, VALE FXR, MORA-AGUILERA G (2004). Análise Temporal de Epidemias. In: Vale, F. X. R., Jesus Junior, W. C., Zambolim, L. Epidemiologia aplicada ao manejo de doenças de plantas. Belo Horizonte: Perfil. .2004; 1, 125-192. 
KUEH TK, GUMBEK M, WONG THA. Field guide to diseases, pests and nutritional disorders of black pepper in Sarawak. Agricultural Research Centre Semongok. Sarawak Lee Ming Press. 1993

MAFFIA JA, RODRIGUES LA, VENTURA CH. Significância epidemiológica do conhecimento do arranjo espacial de plantas doentes no campo: Meleira do mamoeiro. Fitopatologia Brasileira. 2013;26(4), 315.

PRABHAKARAN KP. Agronomy and economy of black pepper and cardamom. The "King" and "Queen" of Spices. London: Elsevier Science Publishing, 2011,1,366.

SHAHNAZI S, MEON S, VEDAMALAI G, AHMAD K, NEJAT N.. Morphological and molecular characterization of Fusarium spp. associated with yellowing disease of black pepper (Piper nigrum) in Malaysia. Journal of General Plant Pathology. 2012,160169. doi: https://doi.org/10.1007/s10327-012-0379-5.

SITEPU D, MUSTIKA I. Diseases of black pepper and their management in Indonesia. In: Ravindran, P.N. Black pepper (Piper nigrum). Medicinal and aromatic plants profiles. Amsterdam; 2000;1,297-308.

VALE FXR, JESUS JUNIOR WC, ZAMBOLIM L.. Epidemiologia aplicada ao manejo de doenças de plantas. Belo Horizonte: Perfil. 2004,1,531.

VENTURA JA, COSTA H. Manejo da fusariose da pimenta-do-reino no Estado do Espírito Santo. Vitória-ES: Incaper. 2004,1,16.

VIDAL CA, LARANJEIRA FF, NASCIMENTO AS, HABIDE TC. Distribuição espacial da meleira do mamoeiro em zonas de trópico úmido e trópico semi-árido. Fitopatologia Brasileira; 2004;29(3),276-281.

ZACCARDELLI M, VITALE S, LUONGO L, MERIGHI M, CORAZZA, L.. Morphological and molecular characterization of Fusarium solani Isolates. Journal of Phytopathology. 2008;156(9),534-541. doi: https://doi.org/10.1111/j.1439-0434.2008.01403.x. 